тұжырымдар жасалынған. Оқушының жеке тұлға болып қалыптасуындағы ролі айқындалған. Жобалап оқытудың тарихы туралы қысқаша сипатта берілген. Жоба әдісінің білім алушылардың кез келген ситуацияларда өз проблемаларын іздеп, тауып, шешуі, өзіндік жұмыстарын, іс-әрекетін ұйымдастыруы екендігі ғылыми тұжырымдалады. Жобалап оқытудың артықшылықтары ретінде оқушының логикалық дәрежеде ойлауы, өз күштері мен мүмкіншіліктеріне деген сенімдерінің артуы, жобамен жұмыс жасау негізінде алған білімінің нәтижесін көрсетуі және өздеріне артылған жауапкершілікті сезіне білуін ұсынылады. Жобалап оқытудың мақсат-міндеттері айқындалып, оқу үрдісінде пайдалану жолдары көрсетіледі. Мектепке дейінгі білім беруде қолданылатын жобалап оқыту технологиясының түрлері ұсынылады. Жобалай оқыту технологиясына қатысты ғылыми ізденістердің уақыт өткен сайын жаңарып, жаңғырып, толығып, дамып отыруы қазіргі білім үрдісіне қажетті үдеріс екендігі айтылады.

Түйін сөздер: жобалап оқыту, моно жоба,пәнаралық жоба, бірпәндік жоба, рөлдік ойындар жобасы, шығармашылық жоба, фантастикалық жоба

\author{
Osmanova Z., ${ }^{1}$ Seysenbayeva $Z h^{2}$ \\ Abai Kazakh National Pedagogical University, \\ Almaty, Kazakhstan
}

\title{
SCIENTIFIC BASIS OF PROJECT-BASED LEARNING TECHNOLOGY
}

Abstract

The scientific article analyzes the importance of studying the technology of project-based learning. It is concluded that the technology of project-based learning has a direct impact on the humanization of the individual as a person, forming the intellectual, professional, moral, spiritual, civic and other qualitative qualities of the student. The role of the student in the formation of personality is determined. Briefly about the history of project-based learning. The design method consists in finding, finding and solving students ' problems in any situation, organizing independent work, activities. As the advantages of project training, it is proposed to show the results of the knowledge obtained on the basis of logical thinking of the student, increasing his self-confidence and capabilities, working on the project and realizing the responsibility assigned to them. The goals and objectives of project-based learning are defined, and the ways of their application in the educational process are outlined. The types of project-based learning technologies used in preschool education are offered. Scientific research related to the technology of project-based learning is updated, updated, supplemented and developed over time.

Keywords: project-based learning, monopoint, interdisciplinary project, one-disciplinary project and role-playing, creative design, fantastic design

\section{Османова 3., ${ }^{1}$ Сейсенбаева Ж.А. ${ }^{2}$}

Казахский национальный педагогический университет имени Абая, Алматьи, Казахстан

\section{НАУЧНАЯ ОСНОВА ТЕХНОЛОГИИ ПРОЕКТНОГО ОБУЧЕНИЯ}

\begin{abstract}
Аннотациия
В научной статье анализируется важность изучения технологии проектного обучения. Сделаны выводы о том, что технология проектного обучения оказывает непосредственное влияние на гуманизацию как личности, формируя интеллектуальные, профессиональные, моральные, духовные, гражданские и другие качественные качества учащегося. Определена роль ученика в становлении личности. Кратко об истории проектного обучения. Научно формулируется, что проектный метод заключается в поиске, поиске и решении обучающимися своих проблем в любых ситуациях, организации самостоятельной работы, деятельности. В качестве преимуществ проектного обучения предлагается логическое мышление учащегося, повышение уверенности в своих силах и возможностях, демонстрация результатов полученных знаний на основе работы над проектом и осознания возложенной на них ответственности. Определены цели и задачи проектного обучения, намечены пути их использования в учебном процессе. Предлагаются виды технологии проектного обучения, применяемые в дошкольном образовании. Научные изыскания, касающиеся технологии проектного обучения, со временем обновляются, модернизируются, дополняются и развиваются.
\end{abstract}

Ключевые слова: проектное обучение, монопроект, междисциплинарный проект, однопредметный проект, проект ролевых игр, творческий проект, фантастический проект

Кіріспе. Қазіргі жаппай жаһандану заманында экономикалық, әлеуметтік, саяси және адамгершілік проблемалар ушығып, шиелінісе түсуде. Осы мәселелерді шешуде қай елдің болмасын, білім сапасының атқарар рөлі зор екендігі айтпаса да белгілі. Себебі, халықаралық аренада әр елдің саяси тұрақтылығының 
сақталуы мен экономикалық бәсекелестікке қабілеттілігі, сол елдің адам капиталының сапалық маңызына байланысты. Осы тұрғыда, қай мемлекеттің білім сапасы жақсы болса, кез келген бәсекелестікте басым түсері анық.Олай болса,тәуелсіз мемлекетіміздің тұтқасын ұстау білімді де, білікті жастардың еншісінде. Ал еліміздің ертеңгі болашағы -мектеп қабырғасынан алған білім нәрімен сусындаған оқушы жастар - бүгінгі студенттер. Сондықтан да, оқушыларға сапалы білім берудің тиімді жолдарын іздестіру, білімге ұмтылдыру өте өзекті мәселе.

Әдістеме. Ақпараттар легінің жылдам қарқынмен ұлғаюына байлынысты, қазіргі білім беру жүйесінің өмір сүруі мен дамуының негізгі принципі - оның үздіксіздігінде. Елбасы Н.Ә.Назарбаев өзінің “Ұлт жоспарының “100 нақты қадам” бағдарламасы аясында, жеткіншек ұрпаққа мектеп табалдырығынан бастап, жоғары оқу орындарына дейін әлемдік деңгейде білім мен тәрбие берілумен қатар, ғылыммен шұғылданудың дағдыларын қалыптастырудың жүйесін құру керектігін алға мақсат ретінде міндет етіп қойды. Бірақ, бүгінде еліміздегі барлық білім беру орындарында өмір бойына, үздіксіз білім алу әлі де болса, толық жолға қойылмай отыр.Осы мәселені шешудің бірден-бір жолы - білім алушының рөлін өзгерту. Педагогикалық процесті ұйымдастыруға жаңаша қарап, сол жаңаны өмірге енгізу қажет. Республикамыздағы барлық оқу орындарында берілетін білім үздіксіз ғана болып қалмай, ғылыми ізденушілікке негізделуі тиіс. Осыған орай, оқу және білім беру қызметін ғылыми тұрғыда ұйымдастыру қазіргі таңда жаңа педагогикалық технологияларды енгізу арқылы жүзеге асырылып жатыр. Білім беру саласындағы жаңарту жұмыстары оқыту, тәрбиелеу, дамытудың жаңа мүмкіншіліктері арқылы ұйымдастырылып, соның нәтижесінде заманауи технологиялармен оқыту үрдісі кеңінен қолданып, насихатталуда. Сол жаңа технологиялардың ішіндегі «жобалап оқыту технологиясы” өте тиімді әдістердің қатарында.

Себебі, жобалап оқыту технологиясы педагогтың интеллектуалдық, кәсіби, моральдық, рухани, азаматтық және басқа да сапалық қасиеттерін қалыптастыра отырып, жеке тұлға ретінде ізгілендіруге тікелей әсер етсе, оқушының жеке тұлға болып қалыптасуына септігін тигізеді. Жобалап оқыту барысындаоқушыныңжас және жеке ерекшеліктері ескеріле отырып, ұстазбен тең дәрежедегіоқу үдерісін жүзеге асырушы болады.

“Әлемнің озық елдерінің білім процесіндегі тәжірибе көрсетіп отырғандай, жобалап оқыту технологиясы өзінің қолжетімділігімен, білім алушылардың қабылдауына жеңілдігімен, барлық педагог-мұғалімдердің қолдануына тиімділігімен ерекшеленеді. Бұл технологияның тағы бір ерекшелігі - барлық пән аясында қолдануға ыңғайлылығы” [1, 12].

Нәтиже. Жобалап оқытудың тарихына тоқталмас бұрын, бірінші “Жоба әдісі” дегеніміздің не екендігін қарастырсақ, шығу тарихы Еуропа елдерінен бастау алатынын байқаймыз. “Жоба” сөзі латын тілінен алынған, projectus “алдыға лақтырылған”, “сөйлеуші”, “көзге түсуші” деген мағынаны білдіреді. Яғни, бір объектінің, бір істің прототипі, прообразы сияқты, осы іс-әрекет жоба жасауға әкеледі. Сонымен, жоба дегеніміз, тікелей мағынасында - жоқты жасауға тырысу, бір нәрсенің алдын алудың жолын көрсету болып табылады екен. “Ал терминологиялық сөздікте “проблема” сөзімен тығыз байланыста қарастырылады.Себебі, проблеманы шешуде жоба шығармашылықтың шынайы көрінісі болады да, оны жүзеге асырушы адам - идеялардың жаршысы болып есептеледі. Жоба әдісі білім алушылардың бір проблеманы шешуін талап етеді. Сол проблеманы шешу барысында олар бір жағынан, әртүрлі әдіс-тәсілдерді қолдануды, екінші жағынан түрлі пәндерден алған білімдерін интеграциялау арқылы пайдалануды үйренеді” [2, 5].

Демек, жоба әдісі білім алушылардың кез келген ситуацияларда өз проблемаларын іздеп, тауып, шешуі, өзіндік жұмыстарын, іс-әрекетін ұйымдастыруы екен.

Жобалау технологиясы әлемдік педагогикада жаңалық емес. Себебі, өз бастауын сонау XIX ғасырдың 2-ші жартысынан, дәлірек, АҚШ ауылшаруашылығы мектептерінен алады. Негізін қалаушы - Америка ғалымы, психолог және педагог, философ Джон Дьюи.

“Дж.Дьюидің ілімін жалғастырушы - Колумбия университетінің жанындағы мұғалімдер колледжінің профессоры, Уильям Херд Килпатрик. Оның ойынша, бұл технологияның негізі - балаларды өз жұмысының жемісін көруге ынталандыру арқылы үлкен өмірге дайындау” [3, 56].

Бірте-бірте жаңа идеялар пайда бола бастады. Белсенді түрде тараған жоба әдісінің жетілген формалары АҚШ, Ұлыбритания, Бельгия, Израиль, Финляндия, Германия, Италия, Бразилия, Нидерландия, Жапон және Ресей, т.б көптеген елдерде нақты проблеманы шешуде пайдаланылып, теориялық білім мен оның практикада қолданылуын қамтамассыз етті.

Қазіргі таңда Қазақстан мектептері бірнеше технологиялармен жұмыс істеп келеді. Атап айтар болсақ, жаңа әдістермен, соның ішінде,жобалау әдісімен оқытатын интеллектуалды мектептер: Назарбаев зияткерлік мектептері, Отандық және халықаралық білім беру тәжірибелерін кіріктіретін инновациялық білім беру моделін құруға негізделген “Мирас" халықаралық мектебі,Almaty International School (AIS), Haileybury, Kazakhstan International School (KIS), Астана қаласының №60 мектеп-лицейі, Абай атындағы №10 дарынды балаларға арналған Павлодар қаласының мектебі, Ақтау қаласының №11 мамандандырылған физика-математика мектебі және В.М.Монаховтың жобалап оқыту технологиясының тәжірибе алаңына айналып отырған Қызылорда қаласындағы №3 мектеп-гимназиялары.

Бұл мектептердің ерекшелігі - мұнда балалардың зерттеушілік, шығармашылық жұмыстары кең ауқымды, идеяларының батылдығы. Білім беруде, ең алдымен, баланың еркіндігіне, қиялына, өз шеберлігіне жол беретін заманауи үздік деген жаңа технологиялармен оқытады. 
Талқылау. Жобалау технологиясын қолданудағы негізгі мақсат - білім алушылардың қызығушылық ынтасын дамыту, өз бетімен жұмыстарын жүргізу арқылы білімдерін жетілдіру, ақпараттық бағдарлау біліктілігін қалыптастыру және сыни тұрғыдан ойлау қабілетін арттыру арқылы болашақта әр түрлі жағдаяттарда, кез келген қоғамдық ортада өзін-өзі көрсете білуге бейімдеу.

“Жоба тақырыбын дұрыс таңдай отырып, жоспарлап, оны дұрыс орындап шығу - болашақта кез келген жағдаятқа бейімделген тұлға болып қалыптасуына септігін тигізеді”[4, 14 ]. Демек, жобалап оқыту технологиясы білім алушының өз бетімен ізденіп, өзіне деген сенімділік күшін оятып, ойын анық жеткізуге, дұрыс оңды шешім қабылдаудың негізінде тұлға ретінде қалыптасуына ықпал етеді. Бүгінгі күн талабында тұрған өзекті мәселенің бірі - білімгерлерді өз бетімен жаттықтыра отырып, зерттеу жұмыстарын ұйымдастыруға үйретіп, жоба жұмысын жасауға мақсатты әрі жүйелі бағыттау. Бұл өз алдында білім беру жүйесінің дамуына тікелей әсер етері анық.

\section{Жобалау технологиясының негізгі міндеттері:}

- алға қойылған мәселені өзбетінше шешуге және оны шешудің тиімді жолдарын табуға;

- қандай да бір түрде безендірілген, нақты, айтарлықтай тәжірибелік нәтижемен аяқталуы тиіс мәселені толық өңдеуге;

- нақты мақсат қоя білуге;

- зерттеу мәселесі бойынша өзектілігін анықтауға (жалпылау, болжау құру, талдау, бақылау, ақпарат жинау, мәселені алға қоюды үйрену);

- қойылған мақсатқа жету үшін, зерттеудің өнімді технологиясын анықтай алуға;

- зерттеу аясының теориялық негізін қарастыруға;

- жобаны зерттеуде зерттеудің ыңғайлы үлгісін таңдауға;

- жүйелік ойлауын;

- іздену арқылы білімін жан-жақты толықтыруға бейімдеп, үйрету.

Жобага қойылатын негізгі талаптар:

- шешімін іздейтін мәселенің болуы, баланың дербестігі және оқытушымен ортақ шығармашылығы;

- оқыту салаларының мазмұнынан таңдалады, яғни мемлекеттік стандарттың талаптарына сай келуі керек;

- тақырып бағдарламадан тыс таңдалып, оқу жоспарының вариациялық бөлімімен сай келуі мүмкін;

- мектепке дейінгі жастағы балаларға жақын және түсінікті болуы керек;

- жоба тақырыбы күнделікті өмірден алынуы тиіс.

“Жоба бір мәселені шешіп және оны қолданыста пайдалану үшін әр түрлі білім салаларынан мағлұматтарды ықпалдастыра алады. Балалар біріншіден ойлауға, ал содан кейін барып істеуге, іс-әрекетінің жоспарын құрып, келісімдерді бұзбай, келісілген мәмілелерден таймауға тырысады” [5, 78].

Қызығушылық 1-2 сабақта немесе керісінше ата-аналардың қатысуымен жобаның жасалуына қарай ұзақ болуына байланысты болады.

жобалаудың негізгі қызметі. Жобалық әдіс - нақты іс-әрекеттер айқындалған кезеңнен бастап жүзеге асатын болады. Жұмысты жасаудағы бағдарлама анықталып, ары қарай жүзеге асыруда қажетті құралжабдықтар таңдалып алынады.

Жобалап оқытудың артықшылықтары. Білім алушылардың логикалық дәрежеде ойлау арқылы, өз күштері мен мүмкіншіліктеріне деген сенімдерінің артуы, жобамен жұмыс жасау негізінде алған білімінің нәтижесін көрсетуі және өздеріне артылған жауапкершілікті сезіне алуы.

Нәтижесінде, берілетін білім сапасы артады. Сонымен қатар, даму деңгейі әр түрлі білімгерлердің мүмкіншіліктері мен өзара ынтымақтасу арқылы қарым-қатынас түсу сияқты іс-әрекет шеберлігі жетіледі.

жобалау әдісінің басты идеясы: оқытушылар мен ата-аналардың көмегі арқылы балалардың танымдық қызығушылығын барынша дамыту және де өз беттерінше өз білімдерін дұрыстап ақпараттық кеңістікте жөн таба білу және сыни ойлауын жетілдіру болып табылады.

“Бұл технологияда жобаға оқушылардың қызығушылығын туғызу басты қиындық болып табылады “[6, 145]. Сондықтан, жобаның маңызын түсіндіру жұмыстарын жүргізу керек болады.

\section{Жобалаудың түрлері.}

$\checkmark$ Жобада басты іс-әрекет түрлері: зерттеу, іздеу, шығармашылық, рольдік, қолданбалы (тәжірибелік бағытталған), таныстыруға бағытталған және т.б. (зерттеу жобасы, ойын, таныстыруға бағытталған, шығармашылық);

$\checkmark$ Жобаның пәндік-мазмұндық ауқымыны қарай бөлінуі: моно жоба (білімнің бір саласында), пәнаралық жоба, бірпәндік жоба. Мысалы: Монопәндік - білім саласындағы мәселелерді шешетін “Денсаулық” жобасы. Пәнаралық - “Денсаулық”, “Коммуникация”, “Таным” сияқты бірнеше білім салаларының мәселесін шешетін жоба, яғни, бір тақырыпты әр түрлі саладағы ұстаным бойынша қарастырамыз. Пәндік немесе пәннен тыс мектепке дейінгі білім беру оқу жоспарының вариациялық бөлігінің мәселесін шешетін жоба.

$\checkmark$ Байланыстық сипатына қарай: қала, аймақ, елдің және әр түрлі елдер арасындағы қатысушылар үшін;

$\checkmark$ жобаға қатысушылардың саны - топтық немес жекелікке байланысты болады;

$\checkmark$ жобаның ұзақтығы - жоба мазмұнының ауқымдығына байланысты, 1 сағаттан бірнеше айға, тіпті 2-3 жылға созылуы мүмкін. 
Бұдан байқайтынымыз, жобалар әртүрлі белгілеріне қарай бөлінетіндіхі. Ең елеулісі іс-әрекеттің басымдық түрі болып табылады.

Мәселен, мектепке дейінгі білім беруде қолданылатын жобалап оқыту технологиясының түрлері.

$\checkmark$ Эмпирикалық: тірі және өлі табиғат әлемінде өздік бақылаулар мен эксперименттер жүргізу. “Қар бүршіктері қайдан ұшып келеді?”, “Неліктен бәйшешектер бәйшешек деп аталады?”, “Қызғалдақ” - ұрып кететін гүл. Нәтижелері: өсімдік сақтайтын бүктемелер, тәжірибе картотекалары ретінде рәсімделеді.

$\checkmark$ 3ертmеу: ізденеді, деректерді жинақтап қорытады,табиғат құбылыстары туралы әр түрлі дерекнамалардан мағлұмат жинайды, кітаптар, кинофильмдер,интернет пайдаланады. Зерттеу, іздестірулер нәтижесі газет айдарлары, альбомдар, журналдар немесе аспаздық кітаптарда жинақталады.Қызыл кітап арқылы (сирек кездесетін және жойылып бара жатқан) өсімдік түрлері мен жануарлар құстар туралы білімдерін кеңейтіледі.

$\checkmark$ Рөлдік ойындар ж⿻басы: бұл шығармашылық ойын нышандары, ойын жобасы.Мұнда балалар ертегі кейіпкерлерінің бейнесіне еніп, берілген тапсырмаларды өздері шешеді. Нәтижесінде: Мазмұнды ойын, бала мерекелері ұйымдастырылады, балалар ертегілерді кейіптендіре біледі.Су асты әлеміне ойын-саяхаттары ойналады. Балалар “Театр” сюжеттік-рөлдік ойындар ойнауға үйренеді.

$\checkmark$ Шыzармашылық жоба: әдетте қатысушыларда ортақ іс-әрекеттерінің дайындалған құрылымы болмайды. Бұл балалардың үлгілер мен пішімдер жасау, әңгімелер құрастыру, тақпақтар, ойдан шығарылған кейіпкерлері бар әңгімелер. Нәтижесінде балалар музыкалық ертегі драмаластыру, столүстілік театры арқылы әңгімелер ойлап табу, кейіпкерлер дайындау, ата-аналар мен балаларға қойылым көрсету мен сахналастырылған,суреттелген диафильмдердің фильмотекасын жасау, альбом дизайны көрмесі. Шығармашылық жобаларда табиғи және құнсыз материалдарды пайдаланған жөн.

$\checkmark$ Фантастикалық жоба: таныс әңгімелер мен ертегілер, мультфильмдерді мазмұнына қарай отырып, және балалардың өз шығармашылығы мен қиялынан “Болашақтың қаласы”, “Келімсектер жерде”, “Суперробот” Бетман сияқты жобалар құру.

Жобава қатысушылар құрамы топ, шағын топ, жеке, отбасы, жұп болуы мүмкін. Жобаның ұзақтывы қысқа мерзімді - 1,2 немесе бірнеше сағат, орта мерзімді -1-2 апта, ұзақ - 1-3 айға дейін. Тәжірибеде мектепке дейінгі білім беруде жобаның орындалуы мектеп жасына дейінгі баланың психикалық дамуына байланысты болады.Әсіресе берілген жобаға деген қызығушылық пен ықыластың тұрақтылығы.

Қорытындылай келе, жобалай оқыту технологиясына қатысты ғылыми ізденістердің уақыт өткен сайын жаңарып, жаңғырып, толығып, дамып келетіндігіне көз жеткіземіз. Себебі, технология билеген заманда білім сияқты ғылым да бір орнында тұрмай, үздіксіз, жедел қарқынен алға дамып, жылжуда. Сондықтан да, өмір ағынынан қалыс қалмай, жаңа технологияларды меңгеріп, ғылым мен білімді ұштастыру аса қажет. Дегенмен, қазіргі таңда оқыту технологияларының жалпы заңдылықтары мен қағидалары нақтыланып, оларды қолданудың өзіндік жүйесі бірізге түсірілген деп кесіп айта алмаймыз. Олай дейтініміз, технология шеберлікпен, өнермен тамырлас ұғым болғандықтан, оның мүмкіндіктерінің шексіз екені аян. Жаңа технологиялардың ішінде жобалау технологиясы еліміздегі білім беру үдерісінде жаппай қолданысқа енуі кем соғып жатыр.

Қорытынды. Осы тұрғыда, жобалап оқыту технологиясын республикамыздағы барлық білім беру сатыларына енгізуде, педагог-мұғалімдерге көмекші құрал болатындай кейбір оқу пәндерінен нақты мысалдар арқылы әдістері нақтыланған жөн. Өйткені, жобалап оқытудың тиімділігі баланы мектеп жасынан ғылымға бейімдеу ғана емес, көзбен көріп, құлақпен естіп, есте сақтай отырып, оқушыны ізденіске, іскерлік пен танымдық ынтаға, шығармашылық қабілетті жетілдіру арқылы түрлі мәселелерді шеше білуге, тапқырлыққа, жаңа ғылыми ізденіске жетелеуде болып табылады.

\section{Пайдаланылван ддебиеттер тізімі:}

1 Білім алушыларды оқува ынталандырудың жолдары: оку-ддістемелік құраль./Құраст.: С.Ж.Пралиев, М.А.Нуриев, Ж.А.Сейсенбаева, А.Е.Садыкова, Д.М.Советканова. - Алматы, 2015. - 116 б.- кітап

2 Сейсенбаева Ж.А. Пути повышения качества проектного обучение в начальных классах. //Журнал “Научный альманах” 2015 №10-2(12) “Педагогические науки” Россия, Тамбов, 31 октября 2015 2. /ISSN24117609, DOI: 10.17117/na.2015.10.02 Информация об опубликованных статьях предоставляется в РИНЦ (договор № 255-04/2015)-75с. - научная статья

3 Сейсенбаева Ж.А. Жобалап оқыту - бастауыш мектеп оқушысының білімін дамыту құралы // "Білім берудегі инновациялыққызмет және кәсіби құзіреттілік” атты республикальққылыми конференция. “Көшбасшы” оқу-ддістемелік ортальвы Талдықорван, 14 қазан 2015ж. -15б. - конференция

4 Нуриев М.А., Сейсенбаева Ж.А., Советканова Д.М. Қазіргі даму кезеңіндегі бес функиионалды 100 қадамды оқу прочесіне ендіру жолдары // “Ұлттық тәрбие”. № 5 (31) 2015ж.- 736. - кітап

5 Нуриев М.А., Сейсенбаева Ж.А., Совтеканова Д.М., Садыкова А.Е.Жобалап оқзыту технологиясының үздіксіз білім беру бавдарында қ̧олданудың тиімділігі // “Ұлттық тәрбие” № 6 (32) 2015ж. - $56 б$. - кітап

6 Нуриев М.А., Сейсенбаева Ж.А. Мәңгілік ел тұвыры -ұлттық тәрбие мен қ̧азақ тілінің дамуы негізінде // “Ұлттық тәрбие” №1(33) 2016ж.-186. - кітап 


\title{
References:
}

1 Bılım aluşylardy oquğa yntalandyrudyñ joldary: oqu-ädıstemelık qūraly./Qürast.: S.J.Praliev, M.A.Nuriev, J.A.Seisenbaeva, A.E.Sadykova, D.M.Sovetkanova. - Almaty, 2015. - 116 b.- kitap

2 Seisenbaeva J.A. Puti povyşenia kachestva proektnogo obuchenie v nachälnyh klasah. //Jurnal "Nauchnyi älmanah” 2015 №10-2(12) "Pedagogicheskie nauki” Rosia, Tambov, 31 oktäbrä 2015 g. /ISSN2411-7609, DOI: 10.17117/na.2015.10.02 Informasia ob opublikovannyh stätäh predostavläetsä v RINS (dogovor № 255-04/2015)-75s. nauchnaia stätä

3 Seisenbaeva J.A. Jobalap oqytu - bastauyş mektep oquşysynyñ bılımın damytu qūraly // "Bılım berudegı innovasialyqqyzmet jäne käsıbi qūzırettılık” atty respublikalyqğylymi konferensia. - “Köşbasşy” oqu-ädıstemelık ortaly̆̆y Taldyqorğan, 14 qazan 2015j. -15b. - konferensia

4 Nuriev M.A., Seisenbaeva J.A., Sovetkanova D.M. Qazırgı damu kezeñındegı bes funksionaldy 100 qadamdy oqu prosesine endiru joldary // "Ūlttyq tärbie”. № 5 (31) 2015j. - 73 b. - kitap

5 Nuriev M.A., Seisenbaeva J.A., Sovtekanova D.M., Sadykova A.E.Jobalap oqytu tehnologiasynyñ üzdıksız bılım beru bă̆darynda qoldanudyñ tiımdılıgı // "Ūlttyq tärbie” № 6 (32) 2015j. - 56b. - kıtap

6 Nuriev M.A., Seisenbaeva J.A. Mäñgllı el tūğyry - ūlttyq tärbie men qazaq tılınıñ damuy neglzınde // "Ūlttyq tärbie” №1(33) 2016j.-18b. - kitap

МРНТИ 16.31.51

https://doi.org/10.51889/2021-1.1728-7804.63

\author{
Рахметова Р.С., ${ }^{1}$ Назарбекова А.A. ${ }^{2}$ \\ 1,2 Абай атындавы Қазақ ұлттыққ педагогикальққ университеті, \\ Алматы, Қазақстан
}

\section{ЭТНОМӘДЕНИ БІРЛІКТЕРДІ ОКЫТУДАҒЫ ЭТНОПСИХОЛИНГВИСТИКАЛЫК ТӘСІЛДЕРДІН ТИІМДІЛІГІ}

Айдатпа

Мақалада этномәдени бірліктерді оқытудың тәсілдері ұсынылады. Этномәдени бірліктер мен лингвомәдени бірліктерді ажырату параметрлері анықталады. Этномәдени бірліктер этнопсихолингвистикалық қағидаттармен ажыратылады. Этнопсихолингвистика заңдылықтары бойынша этноцентризмдік бағыт, яғни этносаралық мәдениеттердің тоғысуы, мәдениет ортақтығының қалыптасуы айқындалады. Сондай-ақ этножіктеуіш белгілер сақталғанда этномәдени құндылықтардың өміршеңдігі басымдыққа ие болатыны айтылады. Мақалада этникалық топтың қарым-қатынас мәдениеті белгілі бір адамдарға тән коммуникативті (белгілік) қызметтің тарихи қалыптасқан психологиялық құралдары жүйесі ретінде талданады. Этникалық топтың қарым-қатынас мәдениетінің құрылымын да, ішкі психологиялық механизмдерін де зерттеудегі семиотикалық тәсілдің мүмкіндіктері талданады. Қарым-қатынастың этномәдени және мәдени-психологиялық сипаттамаларын зерттеуде отандық психологиялық ғылымды жандандыру қажеттілігі атап көрсетілген.

Түйін сөздер: этномәдени бірлік, этнопсихолингвистика, этножіктеуіш белгілер, этноцентризм, құндылық

\author{
Rakhmetova R., ${ }^{1}$ Nazarbekova A. ${ }^{2}$ \\ Abai Kazakh National Pedagogical University, \\ Almaty, Kazakhstan
}

\section{EFFICIENCY OF ETHNOPSYCHOLINGUISTIC APPROACHES IN TEACHING ETHNO-CULTURAL UNITS}

\section{Abstract}

The article proposes a methodology for teaching ethnocultural units. The parameters and distinctive features of ethnocultural units and linguocultural units have been determined. Ethnocultural units differ in ethnopsycholinguistic principles. According to the laws of ethnopsycholinguistics, they are determined by the direction of ethnocentrism, i.e. acculturation of interethnic cultures, the formation of a cultural community. And also, the vitality of ethnocultural values is determined by the relevance of preserving the ethnodifferentiating attribute of ethnoculture. The article analyzes the culture of communication of an ethnic group as a system of historically formed psychological means of communicative (sign) activity, characteristic of a given people. The possibilities of a semiotic approach to the study of both the structure and internal psychological mechanisms of the culture of communication of an ethnos are analyzed. The need to intensify domestic psychological science in the study of ethnocultural and cultural-psychological characteristics of communication is emphasized.

Keywords: ethnocultural units, ethnopsycholinguistics, ethnodifferentiating signs, ethnocentrism, value 